\title{
Aporte de la teología de la liberación \\ a las religiones abrahámicas \\ en la superación del individualismo \\ y del positivismo
}

\author{
Ignacio Ellacuría, \\ Centro de ReflexiónTeológica, \\ San Salvador.
}

Dos afirmaciones, relacionadas entre sl, quisiera presentar, a modo de hipólesis, al proponer a la teología de la liberación (TL) como superación del individualismo y del positivismo contemporáneos y como una perspectiva y base comunes, en que pudieran entroncarse y desde la que pudieran enfocarse tanto el cristianismo como el islamismo y el judaísmo. La primera hipótesis afirma que la liberación implica, de suyo, una conciencia y una actividad comunitaria-colectivas, que superan el individualismo sin negar la individualidad, al tiempo que sostiene muy firmemente la materialidad de la historia, pero abriéndose posititivamente a la transcendencia. La segunda hipótesis sostiene, quizás más hipotéticamente aún que la primera, que en el pasado y en la actualidad un proceso de liberación, debidamente contextualizado y actualizado, podrfa ser un punto esencial de convergencia entre la le y la práctica de las tres religiones abrahámicas.

Antes de entrar en materia, no será ocioso recordar que la TL ha sido acusada de atender más al Antiguo que al Nuevo Testamento 0 , al menos, de no subordinar y/o completar el Antiguo con el Nuevo, por lo cual se le tilda de fundamentarse demasiado en tendencias judaizantes. También ha sido acusada de perderse en consideraciones puramente históricas y aun políticas, perdiendo así el sentido de la transendencia y/o gratuidad supernatural de la fe, olvidando asimismo el carácter personalista de cualquier religión, capaz de responder a las características de la modernidad y a la lectura que de la fe cristiana ha hecho esta modernidad o incluso postrnodernidad.

Hans Urs von Balthasar por un lado, con bastantes malizaciones y valorando en general positivamente los propósitos de la $\mathrm{TL}^{1}$ y por otro las dos instrucciones de la Sagrada Congregación para la doclrina de la fe, ${ }^{2}$ menos positivamente, sobre todo, la primera, son, entre otras muchas pruebas, dos testimonios de cuáles son para algunos 
los peligros principales de la TL en su intento de anunciar la fe cristiana, como liberación. Especialmente Ratzinger ha sido muy crítico, no sólo de la TL sino del conjunto mayoritario de las teologías y movimientos que suscitó el Vaticano II o que acompañaron al concilio. Por poner tan sólo un ejemplo que después retomaremos, el teólogo alemán, revestido ahora de poderes de vigilancia de la fe y la doctrina cristiana, advierte que, al insistir demasiado en la Iglesia como pueblo de Dios, se corre el peligro de quedarse más en el Antiguo que en el Nuevo Testamento, además de quedar, los que eso pretenden, inficionados por tendencias políticas, partidistas y colectivistas. ${ }^{3}$

Estas breves alusiones a críticas habituales a la TL indican, como contrapunto, que el presentar a ésta como superación de ciertos individualismos y positivismos -no excluidos en estos los positivismos eclesiásticos- y como base común de las religiones abrahámicas no es algo gratuito y arbitrario sino que tiene fundamento real. Si a la TL se le ataca en una determinada línea que tiene que ver con estos problemas, es que los ha tratado a fondo y es que sobre ellos ha dicho cosas que han puesto en conmoción puntos de vista que se consideraban sólidamente adquiridos y representativos de lo que es la fe cristiana en su plenitud..

Tenemos con ello introducido el problema, que pretendemos responder en dos parles separadas. La primera, tratará de mostrar cómo la TL supera el inividualismo y el positivismo: la segunda, tratará tentativamente de indicar cómo y por qué su modo de presentar la fe cristiana, lejos de apartarse de algunos puntos esenciales del judaísmo y del islamismo, puede servir de vuelta a aquello que tienen de común y que no está claro haya sido preservado en toda su plenitud y sobre todo revitalizado y actualizado en algunas de las formas que las tres religiones tomaron, cuando desarrollaron lo que en algunos de sus estratos, si no en algunas de sus epocas, fue herencia común. Algunos verán en este regreso a lo común un empobrecimiento de los desarrollos divergentes, pero esto no se puede sostener. La vuelta a los origenes, la radicalización o vuelta a las raíces, puede dar excelentes resultados, siempre que no se haga de modo mecánico y fundamentalista sino de modo creativo y en respuesta a las nuevas situaciones. Tal vez no sea exagerado decir que la TL representa un esforzado empeño por regresar a las raíces por cuanto el contexto social en el que se desarrolla es mucho más próximo al contexto o a algunos de los contextos más creativos del Antiguo y del Nuevo Testamento. Más aún, puede decirse que la TL trata de rescatar, por un lado, la fe cristiana de las manos usurpadoras, de la cultura o civilización occidental y, por otro, de las manos de los más ricos poderosos y dominantes de la tierra para ponerla en manos de sus destinatarios primigenios y privilegiados que son los pobres de la tierra y las culturas o civilizaciones de la pobreza. Ciertamente esto representa una profunda revolución ideológica que no niega el enriquecimiento que ha podido traer al cristianismo su maridaje con el desarrollo humanista, ideológico —en menor grado cientúfico- y económico de occidente, pero que afirma, de una parte los grandes males que ha supuesto al cristianismo ese maridaje hasta convertirse, no tan ocasionalmente, en la ideología justificadora de los paises ricos y de las clases dominantes en su relación con los países pobres y las 
clases dominadas, y afirma, de otra parte, que la tan necesaria revitalización del sentimiento religioso y de la praxis religiosa, propios de las religiones abrahámicas y tan necesario para la humanización de nuestro actual desarrollo histórico, pueden aprovecharse mucho de lo que es la TL y de lo que son sus supuestos tanto religiosos como socio-históricos.

\section{En busca de la superación no negativa del individualismo y del positivismo}

No todo en el individualismo y en el positivismo de la civilización occidental es malo ni ajeno a la fe abrahámica, si es que por esta fe entendemos, como es debido, no sólo la relación creyente de Abraham con un Jahvé trascendente - pero que no por ello olvida promesas y presencias históricas - sino también la acción de Moisés y de tantos otros que completan la gratuidad de la fe con eficaces acciones históricas, en que se concretiza sea como signo, sea como fruto, el carácter histórico-salvífico de esa fe.

Sin entrar en grandes disquisiciones, ni filosóficas ni históricas, puede afirmarse que en la individualización del grupo social, a la que ha contribuido mucho la subjetividad religiosa de la fe cristiana, ha de reconocerse un factor positivo y un crecimiento histórico. La afurmación del Yo como un ser relativamente absoluto, que reafirma su ser propio no sólo frente al resto del mundo sino también frente a Dios, no es, en principio, un pequeño logro del desarrollo de la humanidad y de la humanización, si es que esa reafirmación se hace en religación a la deidad, al poder de lo real en tanto que real, y se hace asimismo sin desconexión con la unidad radical de los hombres entre sí y de todos y cada uno de los hombres con su medio y con su mundo. ${ }^{4}$ Asimismo puede sostenerse que la afirmación de la consistencia de las cosas reales en su más concreta determinación y de los hechos en su más desnuda positividad es un punto de arranque indispensable para alcanzar una transcendencia que para nosotros esta en las cosas y es de las cosas -incluido en ellas muy especialmente el hombre y la historia- y que no puede alcanzarse por tanto sino en ellas tal como ellas se manifiestan en un primer momento en su propia y singular positividad.5 Estos son factores valiosos tanto del individualismo como del positivismo, que nos llevan a proponer el problema en términos de superación y no de negación, aunque eso sf en términos de una superación dolorosa, trabajosa y de profundo significado dialéctico-religioso.

Efectivamente, hay un individualismo de la propiedad privada absoluta, entendiendo ésta en toda su amplitud, y no reduciéndola a propiedad privada de los bienes materiales. Esta absolutización de la propiedad privada consiste en que se es uno mismo separado y contrapuesto a los demás, en que se es propiamente uno cuando se priva a los demás de lo que es suyo y se les somete, en que se apropia uno de sí mismo cuando se apropia de los demás y de lo que es o debiera ser propiedad común y comunicada. Santo Tomás y sus seguidores - éstos muchas veces con mucha menor cautela que aquél- han visto que la dignidad de la persona humana exige la propiedad privada, que algunos extienden hasta la propiedad privada de los medios de 
producción. 6 Pero no han insistido tanto en que cl extremismo de la propiedad privada tal como se ha desarrollado históricamente y tal como aparece ir inscrito en su propia dinámica, lejos de desarnollar la personalidad de cada uno de los hombres y de todos los hombres, la individualiza segregadamente con la consiguiente despersonalización y deshumanización de la mayor parte de la humanidad. ${ }^{7}$

Hay asimismo un posilivismo, que contrariamente a su pretensión de atenerse a lo dado, trata de absolutizarse, csto es, deja de ser positivo. Este positivismo, por decirlo así, achata absolutamente el universo y la historia, además de reducirlos arbitrariamente al convertir en medida absoluta de la realidad no ya al hombre y su inteligencia sino una reducida dimensión del hombre y de su inteligencia. Este positivismo lo abarca todo. Es un posilivismo hermenéutico que se reserva para sí mismo el título de científico, pero es asimismo un positivismo de la felicidad, que queda reducida drásticamente en la misma medida que queda reducido el hombre. Es también un positivismo religioso en cuanto circunscribe la dimensión teologal al rito y al precepto y reduce la dimensión de la cclcsialidad a su vertiente institucional. Es igualmente un positivismo de la política y del derecho, tanto más grave cuanto la política y el derecho que se positivizan son los de las clases y los de los pueblos dominantes. La lista de la positivización falsa y reductora de la realidad podría alargarse, pero no es necesario. El posiuivismo es una de las características fundamentales de la cultura occidental moderna y tiende, por el peso de esa misma cultura, a invadirlo todo y en todas partes. El positivismo, cn todas sus formas, niega todo "más" que supcre o transcienda cl dalo inmediato y se venga así de quienes hicieron de la realidad por antonomasia algo scparado de la realidad empírica.

Planteado así el problerna es claro que no se trata de negar el individualismo o el positivismo, sino tan sólo de supcrarlos dialécticamente reasumiendo sus elementos valiosos en una síntesis nueva que nicgue sus factores negativos. ¿Cómo hace esto la TL? Esta es la cuestión. Sin querer agotarla vamos a proponer algunas tesis esenciales que proporcionan las bases para esta superación. Empezando por las que se refieren más a la superación del posilivismo pasaremos después a las que se refieren al individualismo. Ambos aspectos están relacionados porque en delínitiva el individualismo es una forma de positivismo.

\subsection{Tesis teológicas para una superación del positivismo contempo- ráneo}

No es que la TL haya trabado este tema expresamente. La TL no trata de superar nada, sino de responder a siluaciones históricas, cn las que tal vez no es lo más propio de ellas ni el positivismo ni cl individualismo. Pcro en esa respuesta presenta ciertos puntos esenciales, que pucden ser de ulilidad para resolver este problema.

\section{a) Historicidad de la salvación}

La TL ha insistido mucho, aunque no es esto algo exclusivo de ella, en la historicidad de la salvación. Esta historicidad tiene dos lecturas: la salvación es ella misma histórica en el sentido de que tiene historia y la salvación es histórica en el 
sentido de que afecta a la historia misma, la cual debe quedar transformada por la presencia salvífica de Dios en ella.

Que la revelación y la salvación tengan historia en el sentido de que se vayan dando paulatinamente en la historia con dependencia de determinadas concreciones históricas es un hecho admitido por todos, aunque no se saque de él todo lo que comporta. Para no citar más autores baste con recordar a Cullmann, Pannenberg y Moltmann en quienes esta historicidad se hace presente de modo fundamentante. La revelación y la salvación empezaron históricamente, continuaron históricamente y siguen abiertas al futuro histórico.

Igualmente es claro en todas las religiones más o menos salvíficas que la salvación tiene que ver con lo que ocurre en la historia, aun en los casos en que esta salvación se ha planteado como evasión de lo histórico, por considerar que la historia no sólo es mala, sino que es irremediablemente mala, por lo que la salvación no puede consistir más que en separarse de la historia del modo que se pueda mientras se está en el mundo y de manera definitiva en el momento en que el hombre abandona el mundo. Pero en ouros casos se supone que, aunque la historia tenga mucho de malo, aunque haya un pecado del mundo y aun precisamente por ello es menester salvar la historia, hacer que la historia, en lugar de ser el reino del mal sea el reino del bien, en lugar de ser el reino de la dominación y de la opresión sea el reino de la libertad. El problema puede plantearse y debe plantearse en distintos términos según sea el pecado histórico fundamental en cada caso, pero el fondo de la cuestión es el mismo: hay que hacer recaer el poder salvífico de Dios y de la fe en Dios sobre la historia, por lo que ésta tiene de configuradora de la humanidad, de morada de los pueblos y de los hombres y de lugar de encuentro personal y comunitario con dios. La historia no es sólo positividad sino que es también transcendencia, la historia no es sólo lugar de lo profano sino que es al mismo tiempo lugar de lo divino. ${ }^{8}$

Tomados los dos aspectos a una, fácilmente se ve la transcendencia de la positividad, la superación del positivismo, que supone esta concepción y su correspondiente praxis. En la historia no ocurren tan sólo hechos humanos, sino que ella es de una u otra manera, a la manera del pecado o a la manera de la gracia, la historia de Dios. Puede uno distraerse en la superficie de la historia como puede uno quedar prendido en la periferia o en la epidermis de sí mismo, pero así la historia queda desprovista de su propia realidad no sólo en el orden de la interpretación sino también en el orden de la acción. Quien se atiene tan sólo a la positividad de la historia, esto es, quien es un positivista a ultranza, puede ciertamente absolutizar la historia, pero la absolutiza en lo que tiene de no absoluto, precisamente porque sin saberlo aprecia en la historia algo absoluto, algo transcendente a la misma historia En la historia puede y debe descubrirse una revelación de Dios que sólo en la historia, más allá de la naturaleza, pero sin excluir a ésta, puede darse y a la historia hay que remitir toda la fuerza de esa revelación y de su consiguiente salvación para que la historia se humanice y humanice y en esa plena humanización descubra, todo lo oscura e imperfectamente que se quiera, la presencia vivificadora de Dios.

Se ha acusado muchas veces a la TL de politizar la fe, de reducir la fe a un hecho 
político o, en el mejor de los casos, sociológico. Los que así hablan cometen un doble error. Ante todo, ellos mismos han reducido positivistamente la historia por lo pronto a un plano político, pero más gravemente, desde un punto de vista teológico, a un plano superficial y opaco donde Dios no se hace presente o se hace presente de una manera desdibujada y sin importancia. Después, porque no reconocen que la TL se empeña en descubrir en lo histórico, que abarca lo político, pero no se reduce a lo político, uno de los máximos lugares epifánicos, que si hoy dan más oscuridad que luz, más condenación que salvación, por lo mismo están exigiendo la colaboración del hombre para que se conviertin en lo contrario y se hagan lugares de luz y de salvación. El reduccionismo politizantc de la salvación y de la fe scría precisamente un modo de positivismo y nada más opucsto a la TL que este intento de reduccionismo positivista cuando lo que pretende es todo lo contrario: mostrar la dimensión estrictamente tcologal de todo lo histórico.

No supone esto necesariamente confundir los planos. El positivismo histórico puede tener razón al exigir que sc reconozca la debida autonomía a lo histórico y que no se deje a la carla de la transcendencia lo que necesila explicación estrictamente positiva. Por eso se habla de superación y no de negación. Querer evadir la explicación cientifica de los acontecimientos scría un grave error. Por eso la TL, a la hora de la interpretación y a la hora de la praxis, ha tomado con tanta seriedad el tema de las mediaciones. 9

Esta prcocupación por el carácier lcologal y salvífico de la historia lleva a una preocupación fundamental en conıra de las interpretaciones idolátricas de aquello que sin ser absoluto quiere absolulizarse. Monscinor Romero que había escrito su segunda carta pastoral con el significativo túlulo de La Iglesia, cuerpo de Cristo en la historia 10 y cn su tercera había tralado $\mathrm{cl}$ tema de la Iglesia y las organizaciones populares, ${ }^{11}$ en su cuaria y úllina intenta desenmascarar las idolatrías de nuestra sociedad, que para su situación cran la absolutización de la riqueza y de la propiedad privada, la absolutización de la scguridad nacional y la absolutización de las organizaciones. ${ }^{12}$ Los teólogos de la libcración han enfocado este mismo problema repetidas veces y de distintas perspectivas, al considcrarlo un punto esencial para delimitar cuál es la verdadera presencia de Dios en la historia y cuál es una manipulación idolátrica de esa presencia desde la que, en definitiva, se justifica la muerte de los más en beneficio de la vida de unos pocos, de una vida además que nada tiene que ver con la vida verdadera que quicre Dios para los hombres. ${ }^{13} \mathrm{El}$ positivismo lleva a veces a la absolutización de lo rclativo y con ello desfigura el carácler absoluto de la historia quilando a Dios lo que es suyo y dando a los ídolos lo que no les pertenece, un falso carácier de divinidad que oculta a Dios y hace prisioneros a los hombres.

\section{b) Reino de Dios}

La calcgoría "rcino de Dios" tampoco es exclusiva de la TL, pero ciertamente en ella cobra una importancia fundamental y cs, además, entendida de modo especial. Se ha llegado a proponcrla como cl objclo misıno de la teología, de la moral y de la 
pastoral. Lo mismo que Jesús vino a anunciar y realizar, eslo es, el reino de Dios, es lo que debe constituirse en cl objeto unificador de toda la teología cristiana, así como de la moral y de la pastoral cristianas: la mayor realización posible del reino de Dios en la historia es lo que dcben perseguir los verdaderos seguidores de Jesús. ${ }^{14}$

Cuando la TL insiste tanto en el reino de Dios está insistiendo ante todo, en la fundamentalidad y radicalidad de ese concepto y de esa realidad para la debida interpretación y rcalización de la fe cristiana. Cualquier otra cosa distinta de Dios que se ponga por delante del reino de Dios desarticula y desfigura la fe y la revelación cristiana como totalidades organizadas. Pcro para nuestro propósito actual esta concepción de la fe desde el reino de Dios pone en conjunción indisoluble a Dios con la historia. Lo que Jesús vino a anunciar y a empczar a realizar es esa presencia específica de Dios en la historia, que sc relleja sobre todo en el modo de ser, en las palabras y en las acciones de Jesús. El reino de Dios no es algo abstracto o algo deducible de nuestra idca de Dios, sino algo prenunciado por los profetas y anunciado delinitivamente por el mismo Jesús, aunque no de un modo totalmente acabado. Sobrino, entre los teólogos de la libcración, es quien más ha insistido cristológica y teologicamente sobre este punto. ${ }^{15}$

El reino de Dios evade toda una seric de desviaciones peligrosas. Supera el dualismo reino (terrestre) y Dios (cclestial), de modo que los que cultivan el mundo y la historia estarian haciendo algo meramente positivista mientras que los que se dedican a Dios estarían haciendo algo transcendente, espiritual y sobrenatural. No acepta que el reino de Dios se identifique con la Iglesia y, menos aún con lo institucional de la Iglesia, lo cual supondría, por un lado, la evasión del mundo al interior de la Iglesia y la reducción del reino a una Iglesia reducida a lo institucional y, por otro, un empobrecimiento del mensaje y de la misión cristianas que acaban mundanizando y secularizando la Iglesia al conformarla en su institucionalidad con valores secularistas de dominación y riqueza y sometiendo a ella lo que es mucho mayor que ella, el reino de Dios. ${ }^{16}$ No deja que se manipule cl nombre y la realidad de Dios en vano porque comprueba su invocación en los signos históricos de justicia, fraternidad, libertad, opción preferencial por los pobrcs, amor, misericordia, ete., sin los cuales no se puede hablar de una presencia salvílica de Dios en la historia.

El reino de Dios como rcinado de Dios entre los hombres pone de manifiesto la malicia historica del mundo y con ella el reino del pecado, la negación del reino de Dios. Además de un cierto pecado natural (original) y de un pecado personal (individual), el anuncio del reino y la dificultad de implantarlo hacen presentes un pecado del mundo, que es fundamentalmente histórico y estructural, comunitario y objetivo, fruto a la vez y causa de otros muchos pecados personales y colectivos y que él mismo se propaga y se consolida como la negación permanente del reino de Dios. No es que las estructuras pequen, como algunos hacen decir a los teólogos de la liberación, pero las estrucluras manifiestan y actualizan el poder del pecado y en ese sentido hacen pecar y dificultan sobrcmanera cl que los hombres lleven la vida que les corresponde como hijos de Dios. Esc poder pccaminoso es absolutamente real, es en sí pecado y fruto del pecado -recuérdense las explicaciones tradicionales del pecado 
original-, pero además hace pecar al obslaculizar el dinamismo del reino de Dios entre los hombres, la presencia del Espiritu vivificante entre las potestades y los poderes de la muerte. Recobra así el mal del mundo una dimensión transcendente sin separarse de la inmanencia que le es propia. La destrucción de la naturaleza no es sólo un problema ecológico que pone en peligro la vida y la calidad de la vida, sino que es un problema teológico en el que se maniCiesta la pecaminosidad del hombre y se oculta la gloria de Dios. La destrucción de la vida humana o su empobrecimiento no es ni tan siquiera un problema puramente moral, sino que es tambiên, y sin fisuras o diferenciaciones, un problema teológico, el problema del pecado puesto en acción y el problema de la vida divina negada en la existencia humana.

\section{c) El Jesús histórico y la praxis del seguimiento}

Cuando la TL pone como clave de sus reflexiones al Jesús histórico no está entrando en la problemática europea del Jesús histórico y del Cristo de la fe. Por eso yerra Ratzinger cuando ve en la cristología de Sobrino y de otros teólogos de la liberación una presencia dominanle de Bultmann de olros autores europeos. ${ }^{17} \mathrm{La}$ TL no insiste tanto en la separación del Jesús histórico y del Cristo de la fe y, sobre todo, no hace uso de ella con los presupuesios y las consecuencias de las teologlas más o menos liberales. La idea fundamental de la TL sobre este aspecto es que no hay acceso al Cristo de la fe, sino a través del Jesús histórico y que este acceso a la transcendencia del Cristo sólo fue posible en Jesús por la vida que llevó y sólo es posible al hombre, más que constituyéndose en seguidor -no puramente en imitador- de lo que especialmente en los evangelios se nos presenta como la historicidad material de Jesús, no excluido su carácter político. ${ }^{18} \mathrm{Se}$ trata, en definitiva, de una recuperación integral de la historicidad para, sin identificaciones ni dualismo, hacer de Jesús el lugar por excelencia del encuentro de la divinidad, al ser él mismo Dios hecho hombre, Dios haciéndose hombre y consiguientemente el hombre haciéndose Dios hasta legar a serlo.

El Jesís histórico para la TL es, en su positividad, la superación del positivismo. No es abandonando su condición de hombre ni sus responsabilidades históricas como se constituye en hijo de Dios sino asumiéndolas en su totalidad hasta la muerte en cruz, castigo sin duda poĺrico a una vida comprometida con las vicisitudes de su pueblo en todo aquello que hacla referencia al reino de Dios y al Padre que querfa endiosar a los hombres a modo de hijos en su propio Hijo. La positividad de Jesús no permité, por tanto, ninguna interpretación docetista, sino que en su plena humanidad y en su concreta condición histórica, es el modo específico de la revelación y es también el modo específico de asumpción de lo humano como camino hacia lo plenitud de Dios.

Lo mismo debe decirse de la praxis del seguimiento. El seguimiento es un seguimiento histórico del Jesús que hizo presente la divinidad en la historį Este seguimiento no es meramente moralista, porque este moralismo volvería a caer en una positividad sin transcendencia, esto es, en un positivismo sin espesor histórico, segin la acertada expresión de Juan Luis Segundo. 19 Hay seguimiento porque hay fe 
y no habrá fe si no hubicra donación de la verdad real de Jesús a quien él gratuilamente $\longrightarrow$ mcjor el Padrc - ha decidido amar de un modo especial. ${ }^{20}$ Pero, aceptado todo esto, lo que se da es un seguimiento histórico y no una mera imitación. El seguimiento histórico implica, en primer lugar, que se hace del Jesús histórico un punto de relerencia insustituible tanto en lo que es su vida unitaria y totalmente entendida como lo que es en el desplicgue de sus actitudes, de sus acciones y de sus palabras; por mucho que sea difícil llegar a su ipsissima biografia y a sus ipsissima verba y aceptando de grado que ellas implican ya lecturas e interpretaciones históricas, se las toma como punto de arranque constitutivo. Pero el seguimiento histórico implica, en segundo lugar, que cada uno de los seguidores en particular y en común trata de hacer con su propia biografía, pero en su propia historia, no tanto lo que Jesús haría sino lo que Jesús le manda hacer, -leído este mandato desde lo que él fue históricamente y a la luz de lo que su Espíritu, también a través de los signos de los tiempos, dicta en los corazones que han sido asumidos por él. Ese seguimiento tiene un evidente carácter histórico, pues no sólo se realiza en la historia sino que hace de la historia, integralmente entendida, la materia misma del seguimiento, pero tiene al mismo tiempo un carácter transcendente por cuanto lo tiene aquél a quien se sigue y lo tiene también el Espíritu por el cual y con el cual se sigue, porque el seguimiento está medido y orientado por lo que debe ser el reino de Dios, tal como lo anunció y puso en marcha Jesús.

\subsection{Tesis teológicas para la superación del individualismo contem- poráneo}

Tampoco este tema ha sido atención expresa de la TL. Y la razón de ello es clara. Para la TL ni el positivismo ni el individualismo son peligro de la matriz histórica de la que nace, donde, al contrario, es la transcendencia y la comunidad su aire natural. El positivismo y el individualismo que la TL combate es el de los otros, el de quienes no dejan al pueblo vivir su transcendencia Esto le lleva a lecturas propias de temas fundamentales de la fe cristiana, que relee con gran novedad y creatividad.

\section{a) El pueblo de Dios}

Concebir inicial, pero radicalmente a la Iglesia como pueblo de Dios es un planteamiento esencial del Vaticano II en su constitución dogmética Lumen gentium. Ciertamente esta "popularidad" de la Iglesia ha de entenderse fundamentada en su misterio (cap. 1), pero representa por otra parte la realidad englobante, sólo en la cual tienen sentido y limilación las ulteriores diferencias. Supuesta la presencia del misterio y del Espiritu de Cristo, como clara afirmación de la transcendencia, se arranca con la idea del pueblo de Dios que sustituye el sentido de arriba hacia abajo por el de abajo hacia arriba y, sobre todo, sustituye la consideración del todo desde las partes por el análisis y la valoración de las partes desde el todo. Por otro lado, la referencia al pueblo de Dios -"la Iglesia o el pueblo de Dios" (LG, 13)- sibia el planteamiento en clara referencia a toda la humanidad por cuanto "todos los hombres están llamados a formar parte del nuevo Pueblo de Dios" (lb.), por lo que debe 
extenderse a todo el mundo y en lodos los tiempos, no para disminuir el bien temporal de ningún pueblo, antes al contrario para fomentar, asumir, purificar, fortalecer y elevar todas las capacidades, riquezas y costumbres, de los pueblos en lo que tienen de bueno. Y a su vez eslas riquezas de los pueblos que, en definitiva, son dones de Dios, deben suponer un enriquecimiento de la Iglesia, llamada a ser el pueblo de todos los pueblos, en razón de que Dios lo es de lodos los pueblos y su Hijo se ha introducido visiblemente en la historia y la ha asumido para ser el vehiculador en el que y por el que toda la creación se reconcilie con Dios.

La TL sostiene que si el elemento esencial de su anuncio es el reino de Dios no puede dejar de dar toda importancia al pueblo de Dios. Reino de Dios y pueblo de Dios son dos correlatos inseparables. Reino de Dios, en efecto, no sólo junta la transcendencia de Dios con la inmanencia hislórica del reino, sino que reclama inexorablemente la existencia de un pueblo, entendido estrictamente como tal, como una unidad popular, en la cual tienen plena cabida los desarrollos individuales y personales, incluso en la relación intransferible con Dios, pero que los hace tanto más ricos cuanto más vinculados al carácter comunitario del pueblo de Dios estén. Como en el antiguo Israel, sólo Dios es el verdadero rey de este pueblo y los que están al frente de él son, de un lado, parte de este mismo pueblo y no segregación dominante de él y, de otro, no sustitutivos del único rey de este pueblo, sino eventuales mediadores al servicio del reino y del pueblo. Con ello otras concepciones de la Iglesia que exageran su sacralidad y misticismo o su carácter jerárquico son corregidas doblemente al poner, en primer lugar, al pueblo de Dios como correlato necesario del reino de Dios entendido históricamente y, en segundo lugar, al devolver al pueblo su titularidad de primogénito y de destinatario principal frente a las exageraciones de quienes han concebido el gobierno de la Iglesia como lo hacen los dominadores y reyes de este mundo (Mt. 20, 25-28; Mc. 10, 42-45).

Radicada la eclesiologia de la TL sobre este concepto de pueblo de Dios se ha preguntado por las características propias del verdadero pueblo de Dios, en el cual toda forma de ritualismo positivista queda superado asl como toda forma de individualismo. Puesto los ojos en un preclaro obispo mártir, Mons. Oscar Amulfo Romero, que supo entender lo que era un pueblo de Dios para el reino de Dios en la determinada significación histórica de la situación que le tocó vivir, pueden apuntarse cuatro caracteristicas para que el pueblo de Dios vaya constituyendose en verdadero pueblo de Dios: la opción preferencial por los pobres, la encarnación histórica en las luchas del pueblo por la justicia y la liberación, la introducción de la levadura cristiana en las luchas por la justicia y la persecución por causa del reino de Dios en la lucha por la justicia. 21 Son caracteristicas históricas de algo que es esencialmente histórico y que no entran en contradicción con otras características más dogmáticas (unicidad, catolicidad, apostolicidad y santidad), que deben ser historizadas adecuadamente para hacer del misterio un signo crefble y operante en la historia.

\section{b) Opción preferencial por los pobres y las comunidades de base}

El carácter comunitario, transcendente e histórico del pueblo de Dios ha sido 
interpretado por la TL muy especialmente desde la opción preferencial por los pobres y ha propendido a configurar a ese pueblo y a a Iglesia conforme al modelo de las comunidades de base. Las comunidades de base son así una forma de institucionalidad en la que se superan conjuntamente el verticalismo como mejor expresión de la transcendentalidad, el individualismo como forma excluyente de plantear las relaciones del hombre con Dios y el colectivismo institucionalizado como forma negadora de las relaciones interpersonales. Pero las comunidades de base en la TL tienen como uno de sus fundamentos la opción preferencial por los pobres.

La opción preferencial por los pobres es un elemento esencial de toda la TL y recoge algo que es asimismo esencial en el mensaje bíblico y en lo mejor de la historia de la Iglesia. Lo que más ha dañado a la Iglesia católica y a las iglesias crislianas es haberse configurado según una opción preferencial por los ricos hasta haber permitido, cuando no fomentado, que la fe cristiana sea patrimonio de las clases poderosas y de las naciones ricas; clases poderosas que se han convertido en dominadoras y explotadoras y naciones que se han constituido en colonizadoras y explotadoras. El secuestro y la ideologización de la le cristiana por las clases y las naciones ricas ha supuesto desde el constantinismo una de las manipulaciones más hábiles que se han podido dar en la historia. No es fácil comprender cómo una fe que desde el Antiguo Testamento traía una enorme carga profética a favor de los oprimidos y que en Jesús de Nazaret se convirtió en palmaria manifestación en favor de los pobres, se haya podido convertir en el sustento ideológico de las clases y de los pueblos ricos y dominantes y en el basamento ideológico de apoyo a todos los movimientos conservadores y de rechazo a todos los movimientos revolucionarios. La buena nueva subversiva ha sido transformada en respaldo divino del orden establecido. Hoy día nos encontramos Lodavía con que casi todo el tercer mundo, exceptuando América Latina, no es cristiano, mientras que el primer mundo de los ricos se considera como el depositario privilegiado del cristianismo. Contra este escándalo se levanta la TL, la cual se esfuerza como teoría y como práctica en devolver el evangelio y el mensaje profético a su lugar natural, los pobres, los desheredados y los oprimidos del mundo. La riqueza material no puede convertirse en signo de predestinación. Al contrario, casi todos los movimientos verdaderamente espirituales y verdaderamente cristianos, casi lodos los movimientos auténticamente reformadores han hecho de la pobreza la raíz radical del cambio y lo que es más han atendido a la raiz fundamental de la libertad. La verdadera libertad individual y comunitaria pasa por un proceso de liberación, uno de cuyos pasos es el de la pobreza y el de la comunidad, entendida como comunicación de bienes. Estos movimientos han sido tenidos siempre como sospechosos dentro de la Iglesia y han sido desvirtuados, precisamente para arrebatar a la opción preferencial por los pobres y a la pobreza su carácter de denuncia profética y su eficacia de transformación social.

No se puede simplificar el concepto de pobre, pero lampoco se lo puede mal usar en una equivocidad, dentro de la cual cabe cualquicr categoría de sufrimiento. Aceptada la complejidad y la gradualidad del concepto bíblico y cristiano de pobre, hay que mantener que todavía su sentido principal tiene que ver con la pobreza económica y 
social como fundamento y principio de otras formas de pobreza. ${ }^{22}$ Pobre dice relación a Dios por su desamparo y debilidad, pero lo dice también por su carácter de empobrecido, esto es, de tratado injustamente por el poderoso; en ambos casos, en el primero por razón de la misericordia divina y en el segundo en razón de la justicia divina, los pobres involuntarios son objeto de la preferencia de Dios. Lo son también los pobres voluntarios que dejan lo que tienen para seguir más de cerca a Jesús.

Se da asl un carácter social y comunitario de la pobreza que es, por un lado, efecto del individualismo de la propiedad privada y, por otro, superación del mismo en cuanto se pretende combatir la desigualdad social mediante la superación de ese individualismo y la creación de condiciones estructurales que permilan superar el estadio de satisfacción de las necesidades básicas para enderezar las mejores energías de la humanidad, como se ha repelido tantas veces, no a tener más sino a ser más, no al trabajo explotador sino a la actividad creadora. En la opción preferencial por los pobres no hay sólo un signo de transcendencia, sino que hay también un denodado esfuerzo histórico por superar el individualismo.

Esto se aprecia en las comunidades de base. En las comunidades de base, por lo que tienen de comunidad, hay un claro esfuerzo de superación del individualismo y de la soledad atomizada, de ser tratado como un objeto pasivo y despotenciado, intercambiable con cualquier otra singularidad objetivada. El sentido comunilario es revitalizado y con el se acrecientan las condiciones subjetivas del hombre, ahora no encapsuladas, sino compartidas y reconocidas, pero también la presencia del Espiritu que se da a cada uno en el otro y que cada uno da al otro. Así, la comunidad se constituye en una fuerza nueva para defenderse de la presión social y para presionar socialmente en favor de una Iglesia más humana y de una sociedad más justa. Se dinamiza con ello la Iglesia y la sociedad que, en su extremo ideal y utópico, deberian tender a ser comunidad de comunidades, lo cual ciertamente es más hacedero en la primera que en la segunda.

Pero en las comunidades de base, por lo que lienen de base, se da un dinamismo úpicamente cristiano: el del poder de los sin poder. ${ }^{23}$ En las comunidades de base se reúnen los sin poder eclesiástico y los sin poder económico y político, muchas veces oprimidos o desconocidos precisamente por esa falta de poder, no obstante ser en muchos sentidos la verdadera base de la Iglesia y de la sociedad. Se ha querido simplistamente, cuando no torpemente, ver en esto una lucha de clases o la constitución de una Iglesia popular que se enfrentaría a la Iglesia jerárquica. No puede desconocerse cierta tensión permanente entre la jerarquía, a veces acaparada por las exigencias de lo institucional, y las bases más preocupadas por lo comunitario y profético, pero esta tensión se da dentro de la Iglesia y de ninguna manera pretende llevar a dos iglesias paralelas. Lo que sucede es que este movimiento recupera para las bases, fundamentalmente laicas y seglares, muchos de los atributos eclesiales que se habian tomado exclusivamente para sí las instancias clericales y jerárquicas de la Iglesia.

Se llega asi a una nueva eclesiogénesis ${ }^{24}$ que va a parar a lo que siempre debió ser y hace siglos que no ha sido: la Iglesia de los pobres en la que se aúna toda la potencialidad teologal de los preferidos de Dios y toda la potencialidad humana de quienes 
no han sido y quieren ser sujetos históricos de su propio destino y que en la actualidad constituyen un como muelle contraído que trata de hacer saltar el peso que lo reprime.

El conjunto de estos aspectos (historicidad de la salvación, reino de Dios, el Jesús histórico y la praxis del seguimiento, el pueblo de Dios, la opción preferencial por los pobres y las comunidades de base) muestran claramente cómo la TL es, tal vez sin pretenderlo, una excelente forma de superar el individualismo y el positivismo sin negar lo que uno y ouro tienen de favorecedores del desarrollo humano y del encuentro del hombre con Dios. En todos y cada uno de esos temas se procura unir sin identificar lo inmanente con lo transcendente, lo personal con lo comunitario, lo interior con lo exterior. Es cuestión de desarrollar cada uno de esos aspectos y todos ellos en su unidad para mostrar cómo esto es así y cómo es explicado por los distintos teologos de la liberación. En la segunda parte de este trabajo, al avanzar la hipótesis de que lo esencial de la teología de la liberación puede ofrecer un tonco común a los principios originantes y fundantes de las religiones abrahámicas sin quitar por ello la originalidad diferenciada de cada una de ellas, precisamente por el carácter esencialmente histórico de la praxis y de la teoría de la liberación, quedará tal vez más resaltado o, por lo menos formulado de otra manera, lo que solamente se ha apuntado en esta primera parte.

\section{La TL como elemento común dinamizador de las religiones abra- hámicas}

Es un tópico seflalar lo que debe la TL al Antiguo Testamento, en especial a la teología del éxodo y de los profetas en sus más distintas formulaciones. Incluso se ha reprochado repetidas veces el que la TL haya hecho una lectura demasiado veterotestamentaria tanto de la historia de Israel como incluso de la historia de Jesús. Estas mismas raíces comunes han sido asumidas por el Islam. Todo ello nos hace sospechar y aventurar como hipótesis que la liberación, teologicamente considerada, puede constituirse en clave y enfoque fundamental del movimiento religioso abrahámico y en renovación radical de todo él en sus distintas formas históricas. Mirando al pasado de las fuentes esto parece razonable, aunque lo sea menos si consideramos algunas de las formulaciones y de las instuticionalizaciones históricas, que han ido tomando y que aún hoy día tienen cada una de las tres religiones. De hecho la teología de la liberación, minoritaria en los tres casos, sería una posibilidad histórica, más que una realización comprobada, porque las religiones propenden fácilmente a degradarse, a atemperarse a la situación histórica dominante, más que a convertirse en sal y luz, en levadura y fermento y aun en fuego y hacha que arrasan con el mal que desnaturaliza a los hombres.

Para mostrarlo dividiremos el punto en dos pequeñas secciones, la primera dedicada a subrayar algunos puntos esenciales de la TL y la segunda al modo cómo las tres religiones abrahámicas puedan asumir esos puntos esenciales. 


\subsection{Teoría y praxis de la liberación}

La TL parte de un hecho histórico que, como tal, no es un hecho bruto sino que incluye su propia interpretacion, que no lo desfigura sino que lo ilumina. Este hecho histórico es la constatación de que la inmensa mayor parte de la humanidad vive no sólo en pobreza y, en muchos casos, en miseria sino que esta pobreza y miseria es en gran parte injusta, resultado de acciones injustas que se constituyen a partir de una injusticia estructural que tiene a la mayor parte de los hombres en condición de opresión no sólo económica sino también cultural, social y política. Este mal radical lo juzga inmediatamente como pecado, como el pecado del mundo, porque ningín otro mal hace mayor dafio al hombre ni puede considerarse como negación mayor de la voluntad de Dios sobre la humanidad y sobre los bienes de este mundo.

El mundo occidental capitalista propende a ver en la libertad el mayor bien y en la negación de la libertad el mal mayor. La TL retoma este tema con mucho mayor realismo. Hegel ya habia dicho que en el oriente la libertad de uno se basaba en la esclavitud de todos los demás, que en el mundo greco-romano la libertad de unos pocos se fundamentaba en la esclavitud de muchos y que en el mundo germanocristiano la libertad de cada uno implicaba la libertad de todos los demás. Lo que el mundo occidental no quiere ver es que la libertad de unos pocos sigue dándose no sólo junto a la negación de libertad de muchos, sino también debido a la explotación de esos muchos. La libertad individual y las libertades democráticas se fundamentan en gran medida sobre la propiedad privada y sobre un desarrollo económico que implican la apropiación privativa y excluyente de los grandes recursos de la humanidad hecha por los que históricamente se han constituido en los más fuertes, en los capaces de apropiarse de los excedentes y de obligar a los más débiles a términos de intercambio injustos, sea en el contrato de su fuerza de trabajo sea en el contrato de sus productos. Por lo tanto, la TL no acepta esta concepción de la libertad y mucho menos la práctica hipocrita y restringida que de ella se hace.

Pero no es sólo eso. Bajo la bandera de la libertad se ha llegado a una situación en la cual, concedida a todos la libertad por declaraciones formales, no se es capaz de disfrularla porque ni siquiera se deja vivir a la mayoría de la humanidad. La libertad mal entendida se ha convertido en principio de muerte y no en principio de vida. De entre tanto textos consagrados donde se constata oficialmente esta situación puede recogerse el contenido de la primera de las instrucciones sobre la TL: "El escándalo de irritantes desigualdades entre ricos y pobres ya no se tolera, sea que se trate de desisigualdades entre palses ricos y paises pobres o entre estratos sociales en el interior de un mismo territorio nacional. Por una parte, se ha alcanzado una abundancia, jamás conocida hasta ahora, que favorece el despilfarro; por otra, se vive todavia en un estado de indigencia marcado por la privación de bienes de estricta necesidad, de suerte que no es posible contar el número de víctimas de la mala alimentación."25 Juan Pablo II había dicho con anterioridad en su catequesis dominical de la plaza de San Pedro: l'adessione sincera alla Parola di Cristo non supporta la vergogna dell'ingustizia, dell'oppressione (25 de septiembre de 1983). No puede hablarse de libertad cuando no ha habido una primaria liberación de las necesidades básicas. La 
necesidad es lo opuesto a la libertad y la necesidad básica es lo opuesto a la libertad básica. Los hombres oprimidos por la incapacidad de satisfacer sus necesidades básicas con razón se quejan de que no tienen ni siquiera lo básico de la libertad.

La TL ha retrotraido el problema de la libertad a sus raíces que, antes de ser raíces individuales y subjetivas, son raices biologicas y sociales, estructurales e institucionales. Hará falta llegar al descubrimiento y desarrollo de la subjetividad personal y de las libertades políticas para completar la marcha de la liberación, pero el que unos pocos hayan llegado a ello y a su disfrute, porque han logrado previamente, y hoy les parece connaturalmente, la satisfacción de las necesidades básicas, no puede hacer olvidar que la mayor parte de la humanidad no ha logrado la satisfacción de las necesidades básicas y que atrapada por éstas no puede estar soñando en libertades que de ningún modo le son efectivas. Si la libertad ha de entenderse como plenitud de la vida, la libertad ha de comenzar como liberación de la muerte. No hay así libertad plenamente vivida sin un proceso de liberación, de liberación integral, que lo abarca unitaria y armónicamente todo y a todos, pero que arranca por la liberación de los principados, poderes y potestades de la muerte. No se trata de la muerte que a uno le viene por las llamadas causas naturales, aunque también la fe plantea la solución a este problema, sino de la muerte que los demás causan o por lo menos no impiden. Porque son muchos los que de distinta forma necesitan reprimir a quienes buscan su propia liberación, porque según dicen esa liberación pone en peligro su propia seguridad. $Y$ ¿qué seguridad les queda a quienes no tienen sino miseria y cadenas? ¿No tienen ellos derecho a luchar por su propia seguridad que, en un primer momento, no es sino una lucha por su propia supervivencia?

Todo este proceso de muerte y vida, de dominación y liberación es visto a la par individual y colectivamente y tanto en su dimensión histórico-política como en su dimensión histórico-transcendente. El sujeto de la libertad puede ser individual, el sujelo de la liberación es de una u otra forma la colectividad, el pueblo. Y este pueblo en su proceso de liberación de lo primero que se libra, en el orden de lo natural, es de las necesidades básicas, en el orden de lo histórico, de las injusticias que lo oprimen y en el orden político, de los poderes que lo dominan. Y esta lucha permanente de liberación no la ve con ojos puramente terrenales, sino que la pone en relación directa con Dios. Dios no es un Dios de muerte sino de vida, no es un Dios de la escasez sino de la abundancia, no es un Dios de los grandes opresores sino de los pequefios oprimidos, no es un Dios de la dominación sino de la liberación.

El universo simbólico de los pueblos, que todavía mantienen sus culturas propias, es un universo simbólico popular y religioso. ${ }^{26} \mathrm{La}$ experiencia histórica de los pueblos latinoamericanos en sus luchas de liberación ha mostrado la fuerza histớica y política que tiene su conciencia religiosa liberadora. La opresión y represión, la injusticia social, la miseria de pueblos enteros es un clamor que se eleva hacia el cielo, pero en él no se evade la historia, sino que se trae a Dios a la historia. Se trata de una situación de pecado, no querida por Dios y que Dios a traves de su pueblo no tolerará. Si el poder de los dominadores es grande, más grande será a la larga el poder de Dios en la historia y por ello no desfallecerá la esperanza. Ya no es meramente 
una espera pasiva, que aguarda la intervención divina, sino que es una esperanza activa, que se obstina a veces contra toda esperanza humana, en que el Dios de la gracia y de la predilección, el Dios de la vida y de la justicia, acabará estableciendo su reino entre los hombres, pero no lo hara sin la lucha y sin la entrega hasta la muerte de una vida que ya no es arrebatada, sino que es ofrecida y ofrecida para que los demás tengan una vida distinta de la que ellos tuvieron en su materialidad pero que sobrepasaron en su espiritualidad, en el idealismo de sus luchas, en la entrega por los demás y no sólo por los suyos.

Se puede hablar así de una guerra santa. En cuanto guerra puede tomar las formas más distintas por que no se trata de caer en fanatismo y simplismo ni tampoco en utilizaciones indiscriminadas de cualesquiera medios. Ya antes hablábamos de las mediaciones tanto interpretativas como transformativas. Esto hace que la identificación de las luchas de liberación con la violencia armada, incluso con la violencia revolucionaria, sea una identificación precipitada. Ciertamente en varios lugares de América Latina el mensaje de liberación ha contribuido a que parte del pueblo se haya lanzado a las armas, incluso bajo la conducción de vanguardias marxistas-leninistas. Pero este procedimiento, equivocado o no, no representa la única salida de la lucha social, por lo que esa identificación no puede absolutizarse. Los fundamentalismos carecen aqui de lugar, por que las luchas, sin dejar de ser religiosas, en cuanto buscan la superación del pecado y la instauración histórica del reino de Dios, son luchas históricas,que en los medios deben ser orientadas por la fe y que en las estrategias y tácticas necesitan ser orientadas por otras instancias no religiosas.

Pero nada de esto quita la santidad o sacralidad de la guerra, cuando ésta toma la forma de una lucha del pueblo que busca su liberación. No es que la guerra por ser santa justifique cualquier cosa que se haga en ella, sino más bien que la guerra que se haga sea santa, esto es, sin perder de vista la eficacia, sea en sus propositos ideales, en sus objetivos estratégicos y en sus medios, algo que realmente conduzca, a través de un proceso de liberación, a un reino de libertad, de justicia y de paz. No se hace la guerra en busca del poder $y$, menos aún, de un poder dominante y tirano, sino de una situación tal como Dios la quiere y en la que todos tengan cabida sin desigualdades irritantes, sin dominación de los unos sobre los otros, antes con el mayor respeto de Ia naturaleza y con el mayor ejercicio posible de dar los unos a los otros y de darse los unos a los otros. Sin utopismos falsos, pero alentados por la utopía del reino de Dios y de su reinado entre los hombres.

No por ello ha de pensarse que la TL es un reduccionismo político de la fe ni tampoco, en el otro extremo, una nueva religiosización de la política. La TL tiene claro que todo tiene una connotación política, pero asimismo que la política no lo es, ni mucho menos, todo. Ha sido usual repetir que lo que más le importa a la TL es precisamente no la teología, sino el logro de la liberación integral de las mayorías populares. La afirmación es correcta en cuanto la liberación integral de las mayorías populares está por encima de cualquier elaboración teórica, tal como lo puede ser la teologí. Pero inmediatamente hay que añadir que la TL no se reduce a buscar 
soluciones políticas a la liberación de los pueblos y de las mayorlas populares y que la TL, solo haciendo auténtica teología, recuperará el potencial religioso de la fe y podrá contribuir más eficazmente a la liberación histórico-política e histórico-transcendente de los oprimidos. Debe respetarse al máximo la autonomía de lo histórico y dentro de lo histórico la autonomfa de lo político, pero debe respetarse también la autonomía de lo religioso y de lo teológico, como praxis y como elaboración teórica. Por esos dos motivos, porque lo político y lo teológico deben mantener su autonomia, no obstante sus mutuas conexiones, y por que lo político no es todo ni en la vida humana ni en la historia, no debe caerse ni en un reduccionismo de la fe ni de la teología ni tampoco en un reduccionismo de la política y de la praxis política. No debe caerse tampoco en la separación total de un ámbito y de otro, porque lo histórico, en lo que tiene específicamente de signo de los tiempos o de lugar privilegiado de los signos de los tiempos, contribuye enormemente al enriquecimiento y potenciación de la fe y porque lo religioso - para el caso, el movimiento eclesial práctico y teórico que supone la TL - tiene, como ha tenido, mucho que aportar a la historia de los hombres. No siempre su aporte ha sido positivo, pero ha tenido aportes extraordinariamente decisivos y uno de ellos puede serlo, sin lugar a dudas, el movimiento de la teología de la liberación.

Así, la TL ha vuelto a retractar casi la totalidad del mensaje cristiano, a enriquecerlo y a ponerlo más al servicio de la causa popular. Los clásicos temas de Dios uno y trino, de Jesucristo liberador, de la Iglesia de los pobres, de María madre de Jesús, de los sacramentos como símbolos históricos, de la relectura a fondo de la Biblia y de la tradición, de la espiritualidad, etc., van siendo tratados poco a poco y lo que en un primer momento pudo parecer un reduccionismo de la totalidad del mensaje, hasta el punto de hacer de la TL en el mejor de los casos una tcología regional, se ha visto, con el correr de los tiempos, de la producción teológica continua y de la vitalidad de las comunidades de base, que no era así $y$, sobre todo, que no va a ser así.

Por eso carece de sentido hacer de la TL una visión sacralizante del marxismo, una expresión más o menos afortunada en términos religiosos del materialismo histórico y de su lucha de clases. Tal vez haya de reconocersc en la princra hora y en la primera ola de los teólogos de la liberación cierta ingenuidad optimista respecto de las relaciones posibles - y aun necesarias para algunos- entre la praxis tcologal de la liberación y la praxis política de las vanguardias manxistas-leninistas. Pero, si algo de esto hubo, la lección fue pronto asimilada, por lo que carece de fundamento actual la exagerada presentación de este problema en el caso de la Primera instrucción sobre la leología de la liberación. ${ }^{27}$ Como ha dicho Juan Luis Segundo, muchos de los actuales teólogos de la TL apenas tienen otra relación con el marxismo que la de una discreta cortesía. Pero si ésia es una cuestión de hecho, no por eso dcbe desestimarse el problema de la relación del marxismo tanto con los movimientos criscianos de liberación como del análisis y aun de la teoría marxista con las elaboraciones teóricas de una teología, precisamente en lo que ésta tiene de liberación. Aquí también pucde hablarse de un posible enriquecimiento mutuo, si se salvan las difcrencias. Si en 
algunas partes del mundo más desarrolladas el marxismo ha perdido interés y en otras se lo mantiene como un dogma fosilizado, en varias regiones del mundo y por distintas razones está vivo y coincide en algunos de sus propósitos liberadores $\rightarrow$ más en el término a quo que en el término ad quem-con los propósitos que animan al movimiento de la teologia de la liberación. De hecho se ha dado y se está dando una interacción, que puede ser positivamente enriquecedora, no obstante los peligros que este contacio pueda traer a uno y a otro. Normalmente sólo se consideran los males que a la fe puede traer su relación con el marxismo y a los cristianos con los marxistas; rara vez se atiende a lo que el marxismo puede recibir y está recibiendo de la fe cristiana. Hay marxistas que no desean esta comunicación por los males deformantes que le pueden traer, así como hay cristianos que tampoco la desean por los males que seguramente le han traído. Pero son comprobables también los bienes y una teologia de la liberación fuerte y creyente puede hacer más numerosos e importantes los bienes que los males para la fe cristiana, para el marxismo y, sobre todo, para los pueblos que luchan por su liberación. ${ }^{28}$ Es muy posible que en distintos pueblos del mundo, afectados por la miseria y la opresión, como ocurre en América Latina, siga siendo este un problema vivo, respecto del cual la TL, como teoría y como praxis, pueda ofrecer punlos de vista y de acción provechosos. Hasta ahora la doctrina social de la Iglesia se ha construido más desde los países capilalistas y como intento de reforma del capitalismo, dependiendo además de una teología profundamente deudora de la cultura occidental; al ir poniendo el cristianismo su peso cada vez más en los países pobres, ha llegado el momento de que esa doctrina social de la Iglesia se reconsiruya desde los países oprimidos y como intento de reforma del marxismo, desde las contribuciones de la TL. Podría así lograrse un salto cualitativo en el desarrollo de la misma, que ya se ha venido dando en el orden profético, pero que Lodavía no ha calado suficientemente en el orden doctrinal.

Si esto no puede decirse que se haya logrado todavía de un modo satisfactorio, sí puede decirse que se ha logrado en otro terreno de grandísima imporlancia para la vida de la fe, como es el de la espiritualidad. El mayor desmentido a la acusación de polituzación que se ha hecho contra la TL está en el florecimiento de una nueva espiritualidad. Nueva pero al mismo tiempo radicalmente tradicional como le sucede a toda la TL. Es una espiritualidad que, como la propia TL, ha sido primero vivida y hecha que tcorizada, una espiritualidad que ha sostenido la vida y la muerte de muchos mártires, unos más conocidos que olros, cuya sangre y mernoria está viva y actuante en los pueblos de América Latina y también en otros muchos pueblos. La TL no empezó escribiendo sobre espiritualidad porque la espiritualidad de la TL se deriva de una determinada praxis, que la ha exigido y que al mismo tiempo ha obligado a [ormularla. Es una espiritualidad que junta lo inmanente con lo transcendente, lo individual con lo comunitario, la liberación del pecado estructural con la liberación del pecado personal, la liberación de los poderes malignos y maléficos con la libertad de los hijos de Dios. Una espiritualidad que pretende ser cristiana e histórica y que para ello hace del seguimiento de Jesús histórico el criterio fundamental de la moralidad y también la fuente originante del espíritu. Una espiritualidad que es encarnatoria pero no en cualquier carne, sino en la carne de los oprimidos y de los más pobres, 
donde el Dios encarnado dijo iba a poner con mayor preferencia su tienda y su presencia. Esa espiritualidad está en la vida y en los cantos de los más pobres, en las celebraciones de las comunidades de base, en la poesla de Mons. Casaldáliga y de Emesto Cardenal y de tantos otros poetas religiosos, o en las reflexiones más teóricas y teológicas de Gustavo Gutiérrez y de Jon Sobrino. 29

Se trata, por tanto, en la teoría y en la praxis de la TL de un gran movimiento de renovación y, si se quiere, de reforma de la fe cristiana y de la Iglesia. Un movimiento que pretende ser históricamente universal, que pretende re-tractar todo el mensaje de la fe desde el lugar teológico preferencial que son los pobres y los pueblos pobres y que pretende asimismo interpelar al mundo entero y a las distintas religiones que buscan poner en relación al hombre con Dios, a la historia con la salvacion. Ciertamente no se trata de un universalismo univoco e incambiable porque de distinta forma tienen que ver con la liberación los que pertenecen al bloque opresor y los que pertenecen al bloque oprimido y también los que tienen una cultura oriental y los que la tienen de otros muchos tipos. Nada más contrario al espíritu histórico y liberador de la TL que intentar imponerla de modo fijo y desde fuera a otras situaciones distintas, sea por su desarrollo económico sea por su historia cultural. Tiene que ser cada grupo histórico, religioso y social, el que se plantee desde sus propias raíces cómo debe concebir su liberación integral y cómo debe realizarla. Pero la identidad básica de una situación de opresión y la fe fundamental de que Dios es un Dios liberador son dos sólidos pilares que permiten hablar de una cierta unidad histórica, capaz de aunar más y de fortalecer los movimientos mundiales de liberación.

\section{2. ¿Es la liberación uno de los núcleos esenciales de las religiones abrahámicas?}

La cuestión aquí planteada se abre interrogativamente a la respuesta dada por cada una de las religiones. Afortunadamente la cristiana ya ha admitido oficial y magisterialmente que la liberación y la libertad son temas esenciales del mensaje cristiano, puestos hoy de mayor actualidad por las múltiples formas de opresión que se abaten sobre los sectores más pobres de cada uno de los pueblos y sobre la mayor parte de los pueblos. No había ocurrido así antes ni incluso en el Vaticano II. Cuando se propuso que se enfocase formalmente el problema de la Iglesia desde la perspectiva de una Iglesia de los pobres, se abandonó la perspectiva por los peligros que pudiera traer. Pero el mismo esplritu del Vaticano II, recogido sobre todo por Medellín y también por Puebla, ha encontrado una de sus mejores vías de desarrollo y encamación en la TL.

No conozco hasta qué punto la religión judía y la islámica participen en la actualidad tanto del problema como de su adecuada solución. Marc H. Ellis se ha preocupado incipientemente de este problema y ha considerado importante para los judlos el paradigma de la liberación "que configura el centro de la experiencia judía y la dinámica del cautiverio confrontada al llamado de la liberación. "30 Brevemente sus afimaciones fundamentales serian: (a) una voz autocrítica que proviene de lo más profundo de la tradición judía que busca servir al mundo: (b) contribución del pueblo 
judio hacia adelante con generosidad hacia otras comunidades religiosas o humanistas; (c) una genuina liberación que sólo se da a tráves del discurso crítico y de la actividad responsable a la luz de eventos históricos, haciéndose presente en la historia sin intentar aislarse o ser transcendente de la misma. Obviamente la TL ha aprendido mucho, como ya lo hemos recordado, de la tradición judfa, de modo que ésta sigue constituyendo una de sus fuentes permanentes.

El arranque de la predicación y de la acción de Mahoma tiene mucho que ver con la situación socio-histórica que le tocó vivir. Una riqueza fabulosa se habra concentrado en La Meca, resultado y expresión de grandes desigualdades sociales, que enfrentaban a una pequeña oligarquía con multitud de nómadas atraídos por el deslumbramiento y la riqueza de la metrópoli. Un amplio movimiento de descontento y de insatisfacción iba a preparar la predicación coránica que, en un primer momento, se va a centrar sobre el juicio último y sobre el castigo ejemplar, anunciado a aquellos que vivian en un lujo escandaloso y que privaban a los pobres de los bienes necesarios para su subsistencia. El pueblo árabe había perdido su monoteísmo originario en gran parte por razones comerciales y necesitaba recuperarlo, pero sin caer por ello en las interpretaciones que de él habían hecho judíos y cristianos. Una necesidad de sobrepasar la desigualdad social y superar la opresión así como la de encontrar una identidad popular parecen haber sido dos elementos esenciales del arranque del islamismo, frente a una sociedad religiosa y políticamente alienada y alienante. ${ }^{31}$ Mahoma va a hacer a su modo lo que antes hicieron Moisés y Jesús; tambien el desde una perspectiva y desde una fuerza esırictamente religiosa, más semejante en sus propósitos histórico-políticos a Moisés y a la tradición mosaica que a Jesús y a la tradición cristiana primitiva, aunque ésta tomará pronto una presencia eficaz, que desatará la persecución del imperio, del mismo modo que la presencia religioso-política de Jesús desatará la persecución hasta la cruz por parte de los poderes religiosopolíticos de su tiempo.

Por otro lado, es obvio el enorme peso de estas tres religiones sobre el mundo pasado y presente. Aunque el judaísmo actual no cuenta más que con unos quince millones de adeptos su peso histórico y actual es del todo singular. El cristianismo en sus distintas formas puede estimar sus fieles en aproximadamente mil millones de hombres con una clara tendencia a convertirse numéricamente en religión del tercer mundo y, por tanto, más afín a los planteamientos de la TL. El islam, también extendido vigorosamente por todo el mundo, puede contar asimismo con aproximadamente 700 millones con una fuerza política muy imporlante, parte de la cual se ha ejercitado y se ejercita en térninos de liberación. ${ }^{32}$

No es esto, sin embargo, lo más importante, aunque ya como hecho bruto reclama vigorosamente la responsabilidad de los creyentes. Hay, de una parte, una multitud de hombres que viven en extrema pobreza y en situaciones opresivas y represivas; hay, de oura parte, un enorme potencial religioso que puede confluir en la liberación de esos pueblos y de esos sectores sociales, para los que afortunadamente el mensaje religioso sigue siendo la base de su comprensión del mundo y de sí mismos. ¿Qué sería lo escncial de ese mensaje liberador? 
Ante todo, está la concepción de Dios. De ella depende en gran medida lo que van hacer y el modo de hacer de las religiones. Pues bien, en nuestro caso no se trataria de dar una concepción metafísica de Dios que desentraflase lo que fuera su esencia en si, punto imposible de lograr. Mantenida la unicidad de Dios como elemento básico de la unidad de la creación, de la humanidad y de la historia, y mantenido su fundamental carácter de misterio, lo que importa más en la concepción de Dios es su cara histórica, lo que es Dios para los hombres en la marcha de su historia. Este Dios histórico, cuya unicidad, no obstante el problema de la trinidad cristiana, es mantenido por las tres religiones abrahámicas, ${ }^{33}$ es un Dios que se presenta como un Dios de vida y no un Dios de muerte, un Dios de los injustamente tratados y no un Dios de los dominadores y de los explotadores, un Dios de los pobres más que un Dios de los ricos, un Dios subvertidor de los ordenamientos sociales, económicos y políticos injustos y no un Dios que es la garantía suprema ideologizada del desorden institucionalizado y de la situación que han tratado de implantar, como natural y querida por Dios, los poderosos de la tierra. Los salmos cantan a este Dios y oran a él de las más distintas formas, pero con reiteración e intensidad sorprendentes. Porque él es el altisimo busca a los más bajos en la tierra y los más bajos en la tierra buscan, precisamente por serlo, al alúsimo, que les puede liberar de los dioses intermedios y de los hombres y poderes creados que se quieren comportar como dioses; es el Dios que levanta al pobre del polvo y que suscita al empobrecido desde el estiércol para colocarle entre los príncipes de su pueblo (Sal. 112).

Es importantísimo para el hombre en general y para el pobre en particular esta comunicación con Dios. Sin esta referencia a Dios el hombre se empequeflece y ni siquiera da lo mejor de sí. Sólo en busca de Dios el hombre va trascendiéndose a sí mismo, va superando su pequefiez, su debilidad y su pecado. El positivismo cerrado, el achatamiento humanista dejan al hombre realmente empequefiecido. En cambio, aun el más pobre, tiene acceso a la plenitud de lo humano, aunque las formas expresivas de ello sean de índole particular y limitada, cuando se siente preferido de Dios y con acceso a él. Ciertos dioses se han podido convertir en opio del pueblo, pero el Dios vivo y verdadero es todo lo contrario, es la resurrección del hombre, es la exaltación liberadora del hombre. De la diversión de Dios a la conversión de Dios, de la opresión de los hombres a la liberación de Dios, ese es el camino que salvará a la humanidad desde los más pobres y los más necesitados, por que éstos son en definitiva quienes están denunciando lo que es el hombre dejado a sus solas o, lo que es peor, el hombre que ha hecho a Dios a imagen y semejanza del opresor, del garante de la injusticia insitucionalizada y del pecado estructural. La recuperación del Dios vivo y verdadero, como presencia universal y unificante de los hombres, al que los hombres tengan acceso y a quien acudan en su oración, debería ser uno de los aportes fundamentales de las religiones abrahámicas.

Pero este Dios se hace historia de muy distintas formas. La conciencia de la presencia de Dios en la historia y de su intervención en ella es también patrimonio común de las tres religiones abrahámicas y ha sido recogida muy en particular por la TL. La recuperación de la historia como lugar de la fe es, en consecuencia, un punto 
asimismo fundamental. Todo ello se expresa bien en la realidad del reino de Dios, del pueblo de Dios, tal como son entendidos por la TL. A la presencia y acción de Dios en la naturaleza que no anula las leyes naturales ha de yuxtaponerse la presencia de Dios en la historia que no anula las leyes y las casualidades históricas estrictamente tales. El ideal utópico de esta presencia de Dios en la historia no es ninguna forma de teocracia. La TL huye de toda forma de teocracia dentro y fuera de la Iglesia y no busca para sus seguidores la toma del poder. El poder político podrá ser necesario en la historia, pero por la propia naturaleza de los pueblos y de los hombres, al menos en las etapas históricas transcurridas, está ligado al mal y a la dominación. Podrá estarlo más o menos, pero sicmpre lo está de algún modo, por eso más oculta a Dios que lo descubre. El poder político, y aun toda forma de poder, aunque necesario en alguna medida y aportador de bienes necesarios, no es el lugar desde donde la religión debe operar. El lugar histórico de la fe es la lejanía del poder político de quien debe ser conciencia crítica permanente y la presencia entre las distintas fuerzas sociales en las que se aglutina el pueblo y que son la contrapartida de las limitaciones y de los males del poder político. La historicidad de Dios no es la politicidad de Dios y el pueblo profético de Dios no debe pretender constituirse ni en rey ni en vanguardia política; le toca siempre ser pueblo y como pueblo ser sujeto histórico sin pensar que la mejor manera de lograrlo sea la de constituirse en sujeto estrictamente polftico.

No por eso debe dejar de tener su propio proyecto histórico, que dependerá de las posibilidades históricas y de las distintas identidades culturales. Quizá descripciones utópicas como las de Isaías 11, 1-10, donde la paz entre los hombres, de los hombres con la naturaleza y de la naturaleza entre sf, es el resultado de la justicia hecha a los pobres y de la verdad en la relación entre los hombres, pueden servir de orientación. Pero esto hay que concretarlo y hacerlo. Hoy día es claro que por las vias del capitalismo o del socialismo reales, esto no se ha conseguido ni se puede conseguir, no obstante los bienes particulares imporantes que por esos sistemas se han conseguido. ¿Será necesario hacer recorrer a la mayoria de la humanidad que todavia no ha entrado en el furor hegemónico y dominante, que está tras tanto dinamismo de progreso, esos caminos crucificantes a cuyo final no sólo se acrecienta el abismo entre ricos y pobres, entre los poderosos y los débiles, sino que se llega a tensiones, que ponen en peligro a la humanidad como un todo y la salud mental y psíquica de tanúsimas personas? ¿No habrá llegado el momento en que el espiritu más profundo de las religiones abrahámicas, por ejemplo en su expresión del Sermón del Monte, se vuelva más universal y efectivo para intentar una nueva forma de civilización en que no sea la riqueza y la dominación el elemento esencial configurante, sino la pobreza y el servicio? ¿Por qué no construir una civilización de la pobreza que dé lo suficiente para todos y que permita recuperar el ocio y las relaciones comunitarias y comunicativas?

Para lograr algo de esto es imprescindible entrar en un largo proceso de liberación integral que abarque tanto a lo personal como a lo colectivo, a lo institucional como a lo estructural, a la conversión interior y a la transformación social. No basta el 
cambio de estructuras ni basta con el cambio de corazones sino que, desde la perspectiva del reino de Dios, han de convertirse los corazones y ha de hacerse presente la realidad benéfica de Dios sobre las estructuras del mundo. La salvación que anuncian estas religiones tiene hoy un nombre englobante y preciso, liberación. Liberación de la opresión del pecado y de la dominación del mal; liberación de las necesidades básicas que niegan la libertad y aun la vida; liberación de las estructuras y de los dinamismos económicos de modo que el hombre no sea para la economía sino la economía para el hombre; liberación de la dominación política por la que unos pocos paises deciden lo que han de hacer todos los demás en lo intemacional y unos pocos lo que han de hacer las mayorías en lo nacional; liberación del consumismo ideológico que oprime a las gentes y las explota planteando formas de vida, tras las que sacrifican sus mejores posibilidades personales... No hay por que prolongar ni detallar la lista, pero si hay que subrayar muy enérgicamente la necesidad urgente de superar las gravísimas violaciones de los derechos humanos y las formas represivas contra cualquier movimiento de liberación.

Esta liberación para ser auténtica y para responder a lo que es Dios entre los hombres y para los hombres debe, en esta etapa histórica, constituirse desde una opción preferencial por los pobres. La inmensa mayor parte de la humanidad vive hoy en circuntancias de pobreza no tolerables, esto es, de miseria. No podemos hablar de los grandes avances de la humanidad, cuando cada vez son más los hombres que viven peor, aumentando por decirlo así geométricamente el número de quienes cada vez están peor mientras que sólo aumentan aritméticamente los que viven mejor. ¿Que hacer, por ejemplo, con la enorme deuda del tercer mundo? No se trata de trasladar mecánicamente la solución veterotestamentaria a este problema, pero la teología del afio del perdón podría iluminar una posible solución en busca de un mundo distinto, una vez comprobado que el que existe y el que estamos proyectando con los hechos no responde al bien de la humanidad. La Iglesia católica ya se ha pronunciado en favor de esta opción preferencial por los pobres, pero sus obras no han cambiado mucho después de esta profesión de fe y este compromiso. Las naciones ricas dicen preocuparse por los más pobres, pero más es lo que hacen por empobrecerlas que por sacarlas de su miseria. Las religiones liberadoras, una vez liberadas ellas mismas, mucho podrian hacer para que se iniciara vigorosamente un movimiento irresistible de liberación universal. Lo que se logró políicamente en los todavía recientes procesos de descolonización - una forma de liberación-debiera profundizarse socialmente en formas superiores de liberación. Y a ello tendrían que contribuir aquellas religiones que se estiman portadoras privilegiadas de la justicia y de la libertad para todos los hombres y no para unos pocos. Lo harán con tanto mayor vigor cuanto más regresen a sus orfgenes y fundamentos, cuando con la fe puesta en Dios del que mucho aprendieron en el teatro de la historia, se decidieran claramente por la suerte de los más pobres y oprimidos.

No lleva esto a ningún particularismo ni conduce necesariamente a una división de la humanidad entre pueblos ricos y pueblos pobres, entre sectores ricos y sectores pobres de la población. La confesión de un único Dios liberador Hevagonsigo la 
confesión de una única humanidad. En este punto las religiones abrahámicas no se han constituido realmente en religiones universales. Tienen en alguna medida seguidores creyentes entre todos los pueblos, pero cada una de ellas como que se ha especializado en un grupo de naciones: la cristiana preponderantemente entre las naciones pertenecientes a la cultural occidental, a la llamada civilización cristiana; la islámica preponderantemente en países de Africa y Asia y la judía en sectores sociales más pudientes y últimamente en el Estado de Israel. Pareciera haber llegado el momento histórico de constituir realmente una sola humanidad en que valga más el ser hombres que no el ser miembros de un pueblo o de una nación. No se trata de quitar las diferencias, pero sl de subrayar lo sustancial. La vida y la fe han de vivirse en [ormas historicas muy concretas y de formas personales muy particulares, pero son la misma vida y la misma fe. Hoy el mundo está dividido y enfrentado. El capitalismo hace de lo económico la última instancia determinante de todo lo demás; hay que ver cómo se vende más a precio más alto, cómo se gana y se acumula cada vez más; es el economicismo materialista por antonomasia al que se recubre con apariencias ideologizantes de toda especie. El marxismo-leninismo hace del poder la última instancia determinante de todo lo demás: hay que asegurar el poder del Estado para una determinada vanguardia y también el poder político sobre el mundo; es el politicismo materialista por antonomasia que se recubre también con toda suerte de ideologizaciones. Frente a ellos está la universalidad única de la humanidad, la posible asumpción de la diversidad de los pueblos en la unidad de la humanidad. Es la nueva etapa de la historia y lo es, porque de lo contrario, la humanidad perecerá. Estas llamadas apocalipticas son muy propias de las tres religiones abrahámicas, pero su historicidad está muy fuera de dudas. No será directamente Dios quien destruya la vida sobre la tierra; los hombres autoconvertidos en dioses están ya preparados para hacerlo. Lo están ya haciendo por la expoliación y la polución de la naturaleza, pero están dispuestos a culminar la destrucción con la energla nuclear. Nada más inhumano, nada más antidivino, nada más irracional que este individualismo y positivismo de las naciones que no pueden entenderse entre sí ni llegar a acuerdos más que amenazándose mutuamente con la guerra nuclear. Las religiones de vida, las religiones de promesas utópicas, las religiones monotelstas y monosalvfficas pueden y deben impedir esta locura colectiva y lo harán si instauran el reino de Dios como reino del pueblo entero de la humanidad.

Quiź́ en todo este planteamiento sólo se ha insistido en lo positivo que pueden dar estas religiones desde una TL, la cual tiene también sus peligros y está expuesta a desviaciones. Una de ellas puede ser el exclusivismo y el no tener en cuenta experiencias y perspectivas de otras religiones y de otras teologías. Por eso la TL ha de ser abierta y crítica. Si así lo es, aprenderá a corregir sus errores y limitaciones y si asl lo hace su aponte será sin duda providencial e incluso puede esperarse que decisivo para las religiones y para la humanidad, en delinitiva, para el reino de Dios en la historia.

San León Magno decía: Omnia igitur, que Dei Filius ad reconciliationem mundi et docuit, non in historia tantum praeteritorum novimus, sed etia in presentium 
operum virtute sentimus. ${ }^{34} \mathrm{Ni}$ ha concluido la redención ni tampoco la encamación, mucho menos la resurrección del salvador Jesús. Sobre su misión no sólo sabemos por lo que enseño y lo que hizo, sino por lo que, después de terminada su etapa visible, enseño y lo hizo invisiblemente a través de otras personas y otros acontecimientos. La reconciliación del mundo empieza antes de Jesús y sigue después de él, aunque él sea clave definitiva de esa reconciliación, sea sabiéndose sea sin saberlo. Pero lo importante de las palabras de San Leon Magno es que la totalidad de lo que enseño e hizo el Hijo de Dios no se capta si no se atiende a la fuerza y el poder de las acciones históricas presentes. No podemos quedarnos en el positivismo del pasado, que dejaría inoperante el poder de Dios y la fuerza del Espíritu. Un poder y una fuerza que no se reducen a las fronteras visibles del cristianismo institucional ni siquiera a las fronteras de las religiones abrahámicas, como bien lo ensentó el Vaticano $\Pi$. ${ }^{35} \mathrm{Y}$ en todo ello no debemos olvidarnos de la carne histónica que debe ser salvada aquil, en la misma historia, como signo de una salvación liberadora más total, porque de lo contrario ni la sangre de Cristo nos redimió ni la eucaristía tiene sentido: si caro non salvetur, nec Dominus sanguine suo redemit, neque calix eucharistiae communicatio sanguinis eius est, neque panis quem frangimus communicatio corporis eius est. ${ }^{36} \mathrm{Y}$ más precisamente si para el propio San Irenco esto era así, también lo era aquella otra frase, también muy próxima a la TL, de que gloria Dei est homo vivens y que Mons. Romero glosaba diciendo que así como vaya la vida de los pobres, así irá la gloria de Dios. Si los miembros de Cristo sufren, especialmente los más pobres, es el mismo Jesús el que sufre y si esos miembros viven plenamente es el mismo Cristo, aun exaltado en los cielos, quien vive plenamente.

\section{NOTAS}

1. H.U. Balthasar, "Reflexiones histórico-salvlícas sobre la teologla de la libencion" en CTI, Teología de la liberación, Madrid, 1978, 163-181.

2. Sagrada Congregación para la Doctrina de la Fe, Instrucción sobre algunas aspectas de la leologla de la liberación, Roma, 1984. Instrucción sobre libertad cristiana y liberación, Roms, 1986,

3. J. Rauzinger y V. Mesori, Informe sobre la fe, Madrid, 1985, 55.

4. X. Zubiri, El hombre y Dias, Madrid, 1984, 75-112.

5. X. Zubiri, ib., 148.150.

6. Tomás de Aquino, Summa Theologica, 2-2, q. 66, s.7. León XII, Rerwn novarum. Plo XI, Quadragessimo anno. Vaticano II, Gaudium ef spes.

7. I. Ellacurta, "Le historización del ecneepto de propiedad privade como principio de desideologización," ECA, 1976, 335-336, 425-450.

8. I. Ellecuría, "Historicidad de la salvación cristiana," Revista Letinoamericane de Teologla, 1984, I, 5 . 45.

9. C. Boff, Teologio de lo politico. Sus mediaciones, Salemanca, 1980. G. Gutierrez, "Teologin y ciencies sociales," Revisen Latinaamericano de Teolog ba, 1984, 3, 225-274.

10. J. Sobrino, I. Mariln-Bard, R. Cardenal, (ed.), La voz de las sin voz. La palabra viva de Monsetior Romero, San Salvador, 1980, 67-89.

11. Ib., 91-121.

12. Ib., 145-149.

13. J. Sobrino, "Reflexiones sobre el significado del slelsmo y la idolaurn parn ln leologin," Revista Latinoamericana de Teologla, 1986, 7, 45-81. 
14. I. Ellacurfa, "La Teología como momento ideológico de la praxis eclesial," Esfudios eclesidsticas, $1978,457-476$.

15. J. Sobrino, Cristologla desde América Latina, México, 1976, 45-72. Jesús en América Latina, San Salvador, 1982, 95-114. Liberación con espiritu, Santander, 1985, 143-159.

16. L Boff, Iglesia, corisms y poder, Salamana, 1984. I. Ellacurfa, Conversión de le Iglesia al reino de Dios, Sancander, 1984.

17. J. Razzinger, Vi spiego la teologia della liberazione," 30 Giorni, 3 de marzo de 1984, 48-55.

18. Cfr. Sobrino en los libros ciedos en nou 15. J. L Segundo, El hombre de hoy ante Jesris de Nazaret, Madrid, 1982, I/1, 67.284. L Boff, Jesueristo y la liberacion del hombre, Madrid, 1981. I Ellacurn, "¿Por qué muere Jestí y por qué le matan?," Misión abierta, Marzo, 1977, 17.26.

19. J.L Segundo, El hombre de hoy ante Jesús de Nazaret, Madrid, 1982, I. 303-368.

20. Sobre el concepto de fe, efr. Zubiri, 1. c., 209-304.

21. I. Ellacuria, "El verdadero pueblo de Dios, seginn Mons. Rarnero" an Conversión de lo Iglesia al reino de Dios, 1.c.

22. I. Ellacurra, "Pobres" en Concepras fundamentales de pastoral, Madrid, 1983.

23. J.B. Libanio, "Comunidades eclesiales de base. En tomo a temo base," Perspectiva teologica, 1986, 63-76.

24. L Bof, Eclesiogénesis, Santander, 1979. Quiroz, Eclesiologí en la teologla de la liberación, Selamanca, 1983. J. Sobrino, La resurreceión de la verdadera Iglesia, San Salvador, 1986. I Gonzalez, Faus, "Los pobres como lugar teológico," Revisia Latinaamericana de Teologla, 1984, 3 , 275-308.

25. Instrucción primera, 6.

26. V. Codina, "Una teologí mís aimbslica y popular," Revista Latinoamericana de Teología, 1986, 8. 159-179.

27. J. L Segundo. Teologla de la liberacion. Respuesta al cardenal Ratzinger, Madrid, 1986. I Ellacuris, "Estudio teológico-pastoral de la Instrucción..." Revisla Latinoamericana de Teologia, 1984, 2. Varios, "Reacciones de los teólogos latinoamericanos a proposito de la Instrucción" ib., 225 251. L Boff y C. Boff, "Carts ebiers al cardenal prefecto de la Congregación parn la Doctrina de la fe," Misiones exiranjeras, 1986, 325-336.

28. Como visión mis pesimiste de este problemn, efr. Instrucción primera. Como visión crílica, $P$. Amupe, "Sobre el andisis marxisu," Rama, 1980. Como visión optimista. I Ellecurí, "Theologie der Befreiung und Mnrxiemus" en Rolender, P. (Hng.), Theologie der Befreiung und Marzimus, Münster, 1986. Como vision mu optimirn, Frei Betto, Fidel y la religión, La Habana, 1985.

29. G. Gutitrez, Beber de su propio pozo, Lima, 1983. J. Sobrino, Liberación con espúritu, Santander, 1985. Cfr. los múliples testimonios que aporta quinceralmente Carta a las iglesies, publiada desde 1981 en San Salvador por el Centro de Reflexión Teologica de la Universidad Centroamericana "José Simeón Cứlas."

30. M.II. Ellis, "Apuntes pan una teología judí de la liberación," Pasas, 1986, 15-22.

31. T. Fahd, "Naissance de lTslam," En Histoire des religions, 2, Paris, 1972, 646-694.

32. R. Ganudy, Biogropohie du XX'eme siecie, Parrs, 1985. Le tesinment philosophique de Roger Garaudy.

33. M.J. Seanlon, "Fidelily to Monoheism. Christinnity and Islarn," Vidjajyoti, 1986, 283-304.

34. San Leon Megno, Sermo 12 de passione, 3, 6-7, PL, 54, 355-357.

35. Vaticano II Nasira aetase, Roma 1965.

36. San Ireneo, Adversus haereses, Lib. 5, 2, 2-3. 